\title{
Shelagh Farrell: 'Dentistry must be pretty much the only branch of medicine that hasn't got its own royal college'
}

Interview by Adrian O'Dowd

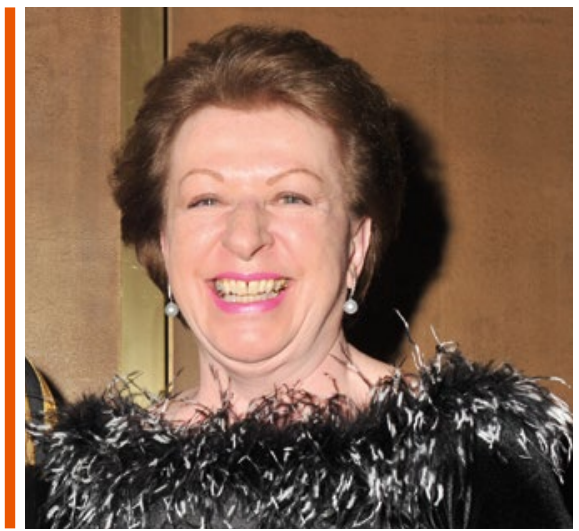

Among the many branches of healthcare, dentistry is well respected but so far, it's missing one crucial facet that most other types of clinicians enjoy - a royal college.

However, change is on the way, according to Shelagh Farrell, specialist in prosthodontics, award winning dentist and long-standing advocate for such a body.

Shelagh has a well-respected career in dentistry that began in 1971, shortly after which she set up her own NHS dental practice near Bristol where she worked for more than 20 years.

Now a semi-retired specialist in prosthodontics in Surrey, she completed an MSc in Conservative Dentistry at the Eastman Dental Hospital, was a part-time clinical lecturer at King's College London and has been on various committees and boards of the Royal College of Surgeons and held high office at the British Dental Association, the General Dental Council and the British Society of General Dental Surgery.

\section{Faculty to College}

Currently, the Faculty of General Dental Practice (FGDP) - established in 1992 - sits within the Royal College of Surgeons of Eng-

Shelagh Farrell is a specialist in prosthodontics with a long career in dentistry that has included running her own NHS dental practice, lecturing, serving on the General Dental Council, BDA, and being Vice-Dean of the Faculty of General Dental Practitioners. She is to be an ambassador for the soon to be fully established College of General Dentistry.

land but it intends to have an autonomous future by transforming into the College of General Dentistry, due to be fully established next year.

Shelagh was instrumental in the birth of the FGDP as a separate faculty within the Royal College of Surgeons, dedicated to the practice of general dentistry.

'We wanted an academic home for general practitioners,' she explains. 'We always intended to form a college of dentistry and we promised the Royal College of Surgeons when the FGDP was first established that we would stay for ten years - 28 years later we're still trying to move!

'Four years ago, our board voted to come out and form a College of General Dentistry and we are still there. This should have been a seamless move but it has gone on and on. Whatever happens, next year they will leave and the FGDP will cease to be, as the College is fully established.'

The College of General Dentistry, which is being established, says it will build on the achievements of the FGDP, which has had a substantial impact in setting standards for the profession while operating under the umbrella of the Royal College of Surgeons. It also intends to seek Royal College status.

Asked why it is important to have an independent college, she says: 'Dentistry must be pretty much the only branch of medicine that hasn't got its own royal college. Governments tend to listen to royal colleges. I think it's time we moved on. I have been asked to be an ambassador for the College and I am happy to do that.'

When this happens, it is likely that the College will want to join the Academy of Medical Royal Colleges, which is the coordinating body for the United Kingdom and Ireland's 23 medical Royal Colleges and Faculties, most of which are colleges.

The Academy's purpose is to ensure that patients are safely and properly cared for by setting standards for the way clinicians are educated, trained and monitored throughout their careers, benefiting from a cross-specialty perspective.

\section{Postgraduate champion}

It is not surprising that Shelagh has been a passionate campaigner for a college of dentistry to become a reality as she embraced postgraduate education from an early stage in her career. 
14 She was one of the first candidates to obtain the Membership of General Dental Surgery (MGDS) qualification from the Royal College of Surgeons and subsequently became a course organiser, tutor and mentor for the MGDS, helping others to achieve the same high standards of patient care.

The Faculty of Dental Surgery, another independent body housed within the Royal College of Surgeons of England, proposed the MGDS for general dental practitioners which was first held in 1979, which, effectively, led to the eventual creation of the FGDP.

However, Shelagh was one of those key people who persuaded the Royal College of Surgeons to set up the Advisory Board in General Dental Practice in 1982, then for it to be transformed into an independent faculty within the college.

\section{Women in dentistry}

Shelagh graduated into what was an overwhelmingly male profession at the time in the 1970s, of which she says: 'In our year out of about 60 people, only eight women qualified and in the year below us, there was only one woman.

'There weren't so many women at all. Now it's over $50 \%$ women in dentistry.

'I have been sitting on committees for years and often been the only woman there, but it has never held back my career. Dentistry was the right thing for me and I have enjoyed my whole career.'

The achievement of starting an NHS practice from scratch in Frampton Cotterell, near Bristol does not seem to have been as daunting as might be imagined for Shelagh, who explains: 'After opening the practice, within six weeks, I was booked up. Within 18 months I was booked up for six weeks ahead and so I employed an associate. I then enlarged the building and employed a hygienist and an orthodontist.

'When I took on an associate, I thought it would be better to have a male associate so people had a choice. Sometimes young teenage boys don't want to be treated by a woman!'

\section{Prosthodontics}

Her first husband John Farrell was a consultant in prosthetic dentistry at United Bristol Hospitals, which is how she became interested in prosthodontics and they worked the introduction of specialist lists,' she says. 'I didn't like the idea that people were claiming to be what they were not trained to be. It's also a check for dentists in referring patients to specialists as to their qualifications. After some arguing, it went through, but I did fight quite hard for that.'

During her time contributing to the BDA for more than three decades, Shelagh was the first woman to be elected to BDA Council and she says: 'I enjoyed that time very much and was president of two branches. I started my politicking with the BDA.'

Her hard work was recognised last year

\section{'I don't think all the dental schools are teaching complete denture construction and I think that's a grave mistake. Implant dentistry must be restoratively driven.'}

together part-time in a private practice in Clifton Down, Bristol, between 1972 and 1981, when John died.

'Prosthetics is a good specialty because you can make people look so much better and you can put the teeth in whatever position you want to. It's a bit of a dying art these days,' she says. 'I don't think all the dental schools are teaching complete denture construction and I think that's a grave mistake. Implant dentistry must be restoratively driven.'

\section{Service to dentistry}

Shelagh was a member of the General Dental Council for many years and served on various committees there.

'One of the things I was keen on seeing was as Shelagh was the first ever recipient of the Faculty Medal - a newly instituted award of the FGDP in 2019, described as the highest honour the FGDP bestows to recognise the most exceptional contributions to the general dental profession through the Faculty.

At the time of the award, FGDP Dean, Ian Mills said: 'Shelagh has made an extraordinary contribution to her patients, her peers and the wider dental profession, and her influence in particular in the establishment and evolution of the Faculty of General Dental Practice over the last 27 years cannot be overstated.'

With such an ally in Shelagh, it seems that nothing can stop the full establishment of the College of General Dentistry next year - an important achievement for dentistry.

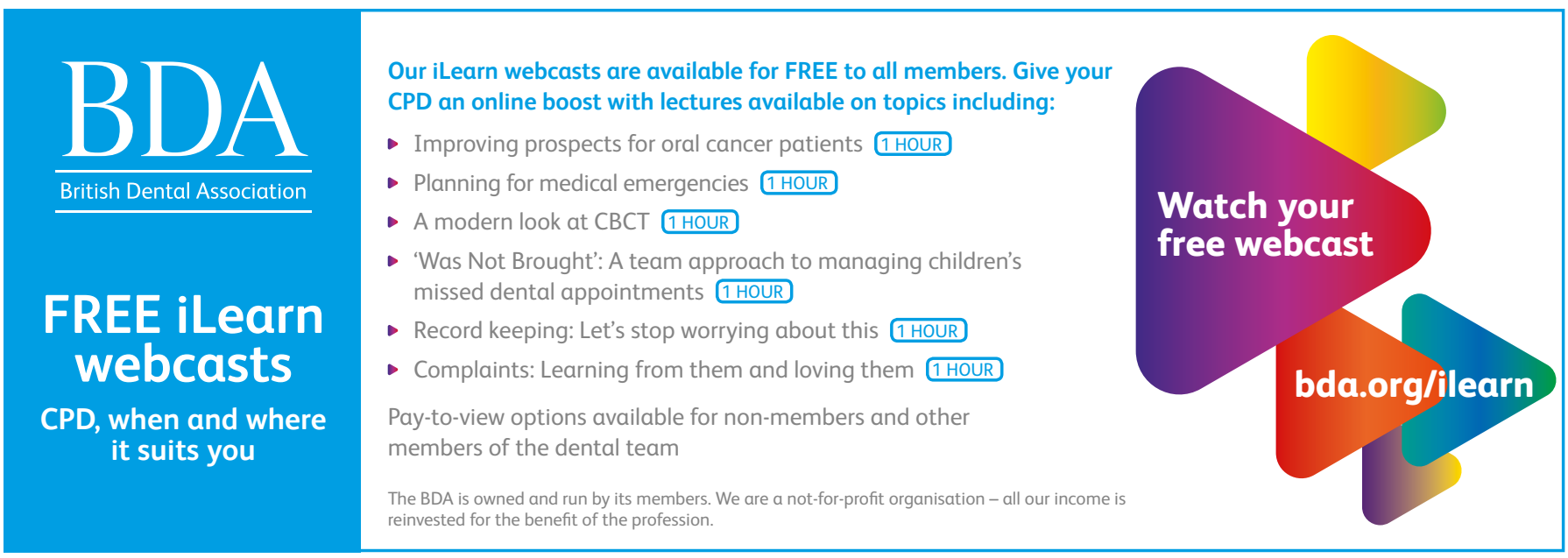

